pp. 101-121

Jasmina AL-DOURI

ORCID: 0000-0002-4484-1384

Instytut Pedagogiki

Wydziat Naul Spotecznych

Uniwersytet Gdański

\title{
Grupy zamknięte na portalach społecznościowych inspiracją dla nauczycieli edukacji plastycznej Świat plastyki w wirtualnej rzeczywistości
}

\begin{abstract}
Closed Groups in the Social Network - an Inspiration for Teachers in Art Education: The world of visual arts in virtual reality

The article is a report on research that was carried out on closed groups on a social media with art education. It shows the exact structure of the group. It paints a picture of the netiquette that reigns in closed communities. It determines the area and creates a list of places where you can receive specific tips on teaching tools and materials as well as lesson plans in art education, along with the effects of creative and artistic activities. Groups that inspire creative activities with children in the school space are described. The presented areas create an ideal and safe place to exchange experiences for teachers dealing with art education from the first stage of education. Virtual space inspire and bring practical knowledge about the principles of designing didactic tasks and the language of art at the elementary level.
\end{abstract}

Keywords: art education, virtual world, preschool education, Facebook, social media, netiquette, primary school, teacher, guide

Słowa kluczowe: edukacja plastyczna, świat wirtualny, edukacja przedszkolna, edukacja wczesnoszkolna, portal społecznościowy, Facebook, netykieta, nauczyciel, poradnik

\section{Pomysł na badania... jako wstęp}

Pomysł na badania rodził się powoli i był związany z zainteresowaniami oraz rozwojem umiejętności zawodowych. Absolwentka edukacji przez sztukę poszukiwała inspiracji i wskazówek praktycznych do pracy w obszarze artystycznym (plastycznym). Rozwijała własne kompetencje i umiejętności podczas licznych 
szkoleń i warsztatów. Przeglądając literaturę przedmiotu, nie znalazła wielu opracowań dotyczą cych pracy z dziećmi na różnych poziomach kształcenia, począwszy od pierwszego etapu. Najważniejsze było dla niej, by ciekawie prowadzić zajęcia, inspirując dzieci do twórczych działań i mieścić się w czasie szkolnym. Wiedząc, jak ważna jest wrażliwość artystyczna i kreatywność twórczych działań dziecka od najmłodszych lat, rozpoczęła indywidualne poszukiwania. Podręczniki metodyczne do nauki na poziomie kształcenia zintegrowanego oraz przedszkolnego nie zawierały odrębnego opracowania edukacji plastycznej. Rozpoczynając pracę z dziećmi na pierwszym etapie kształcenia, dostrzegła, jakie problemy metodyczne napotyka nauczyciel plastyki.

Dopiero dla kolejnego etapu kształcenia opracowano pełen zestaw podręczników dopasowanych do podstawy programowej w zakresie plastyki. Nie jest jednak doskonały. Nie ma jednego podręcznika, który zawiera zestaw ćwiczeń i zadań plastycznych dostosowanych do każdego poziomu rozwoju dziecka. Działania plastyczne dziecka można by dostosować i uporządkować chronologicznie, dopasowując do kalendarza roku szkolnego, aby rozwijać postawy twórcze i wychowywać człowieka uczestniczącego w kulturze.

Dlaczego badania na grupach zamkniętych? W swoich poszukiwaniach eksplorowałam kolejne obszary. Kiedy nastała era nowych nowych mediów i powstał portal społecznościowy Facebook, stał się on miejscem poszukiwań inspiracji. Dla wielu grup zawodowych stał się też doskonałym terenem wymiany doświadczeń, a ja zostałam członkiem grup zajmujących się edukacją plastyczną.

\section{Edukacja plastyczna w przestrzeni szkolnej}

Edukacja plastyczna jest obowiązkowa $\mathrm{w}$ wychowaniu przedszkolnym oraz w kształceniu ogólnym w szkole podstawowej i średniej ${ }^{1}$. Tworzy zintegrowane zajęcia dla poziomu I i II kształcenia oraz odrębny przedmiot - plastyka - na III i IV etapie nauczania ogólnokształcącego. Często problem stanowi dobór ciekawych scenariuszy zajęć praktycznych dla określonej grupy wiekowej dzieci. Każdy nauczyciel planuje i konstruuje własny warsztat dydaktyczny wyposażony w narzędzia i materiały dopasowane do konkretnego zespołu. Nauczanie plastyki jest procesem, który kształtuje postawy twórcze, rozwija wrażliwość i kształtuje społecznie. Uruchamia doznania estetyczne oraz uczy analizy i interpretacji rzeczywistości.

Wymaga to znajomości tradycji nauczania plastyki oraz aktualnych założeń programowych i pakietów edukacyjnych, a także podstawowej znajomości dzia-

${ }^{1}$ Podstawa programowa - Rozporządzenie Ministra Edukacji Narodowej z dnia 14 lutego 2017, http://isap.sejm.gov.pl/isap.nsf/download.xsp/WDU20170000356/O/D20170356.pdf (dostęp luty 2021). 
łania systemu edukacji. Nauczyciel ma obowiązek doskonalić się, rozwijać swoje kompetencje i umiejętności². Aby wzbogacać metodyczny warsztat pracy, uczestniczy w szkoleniach i konferencjach, dba o rozwój zawodowy, poszukując nowych inspiracji, by tworzyć ciekawe i twórcze zajęcia dla określonej grupy wiekowej dzieci.

Trzeba rozwijać percepcję, wrażliwość i wyobraźnię dziecka, stosując różnorodne metody, formy i techniki podczas zajęć z plastyki. Jest to dość trudne, ponieważ nie zawsze mamy łatwość połączenia wszystkich elementów, by stworzyć ciekawe lekcje w szkole. Nauczyciel poszukujący inspiracji jest otwarty na nowe obszary poznania, dzięki którym będzie mógł spełnić wymagania do pracy z konkretną grupą dzieci. Na uwagę zasługuje świat wirtualny, dostępny obecnie dla każdego.

\section{Grupy na Facebooku}

Ważnym miejscem wymiany poglądów są portale społecznościowe. Odkąd powstał Facebook w 2004 r., każdy może do niego dołączyć. Powstał jako portal dla studentów Uniwersytetu Harvarda, założony przez Marka Zuckerberga, ówczesnego studenta zainteresowanego tworzeniem stron internetowych „zawierających komponent społeczny" (Kirkpatrick, 2011, s. 32). Użytkownicy portalu dzielą się linkami, tekstami, zdjęciami, filmami oraz wymieniają poglądy i dyskutują. Przynależność do określonych grup stanowi „fundamentalny element życia w sieci” (s. 196). Większość użytkowników wykorzystuje swoje profile bardziej na płaszczyźnie „osobistej niż zawodowej” (s. 204). Obecnie jednak można zaobserwować, że pojawia się większa ilość profilów, które mają charakter wyłącznie związany z wykonywaną profesją ${ }^{3}$.

Facebook tworzy mnóstwo społecznościowych grup zamkniętych, do których nie zawsze mamy bezpośredni dostęp ${ }^{4}$. Powstają nowe grupy zamknięte, które łączą profesjonalistów w określonej specjalności artystycznej (plastyka, historia sztuki, fotografia, sztuki wizualne), by udostępniać informacje i wymieniać się wiedzą.

Raport z przeprowadzonych badań na portalu społecznościowym w grupach zamkniętych zajmujących się edukacją plastyczną został opracowany w $2019 \mathrm{r}$. Stanowi opis miejsc-grup, w których są przedstawione konkretne tematyczne efekty działań plastycznych będące atrakcyjną formą inspiracji dla nauczycieli.

${ }^{2}$ Karta Nauczyciela - Ustawa z dnia 26 stycznia 1982, DzU, 2019, poz. 2215), https://www. prawo.vulcan.edu.pl/przegdok.asp?qdatprz $=$ akt\&qplikid=2 (dostęp luty 2021).

${ }^{3}$ Dane z przeprowadzonych badań własnych dotyczą zamkniętych grup na portalu społecznościowym Facebook.

${ }^{4} \mathrm{Na}$ podstawie przeprowadzonych badań własnych na Facebooku. 
Mogą one być wykorzystane w pracy dydaktycznej na określonym poziomie kształcenia w danej grupie wiekowej. Grupy zamknięte zajmujące się edukacją plastyczną tworzą nowoczesne środki dydaktyczne, uatrakcyjniając $\mathrm{w}$ ten sposób proces kształcenia, podnosząc efektywność nauczania przez aktywizację uczniów i rozwijanie ich kreatywnego oraz twórczego myślenia, doskonaląc umiejętności.

Całość badań jest zgrupowana w jednym miejscu i czytelnie opisana. Grupa zamknięta jest przypisana do określonego obszaru poszukiwań, co daje pełny i bogaty materiał. Można w niej znaleźć ćwiczenia i scenariusze zajęćs. Wszystko to razem tworzy kompendium wiedzy i narzędzi dydaktycznych dla nauczycieli do wykorzystania w pracy od pierwszego do trzeciego poziomu ogólnokształcącego kształcenia plastyki.

Sprawozdanie z przeprowadzonych badań na zamkniętych grupach zajmujących się edukacją plastyczną na portalu społecznościowym Facebook jest pierwszym tego typu opracowaniem. Powstało na podstawie obserwacji przeprowadzonych na grupach zamkniętych oraz badań ilościowych - kwestionariusza ankiety. Badania będą powtórzone, aby poznać, w jaki sposób wykorzystywane są działania plastyczne w kształceniu on-line.

\section{Raport $\mathrm{z}$ badań ilościowych na podstawie kwestionariusza ankiety w grupach zamkniętych zajmujących się edukacją plastyczną na portalu społecznościowym}

Celem przeprowadzenia badań było poznanie członków grup zamkniętych zajmujących się edukacją, zwłaszcza edukacją artystyczną — plastyczną oraz zwrócenie uwagi na charakter i zasady komunikacji w świecie wirtualnym. Interesowało mnie, jakie są interakcje w grupie, czego dotyczą, kto angażuje się w działania grupy, jaki jest cel tych działań, do czego członkowie wykorzystują „bycie w grupie”, gdzie i w jaki sposób wykorzystują zaczerpnięte stamtąd inspiracje i pomysły.

Kwestionariusz ankiety zawierał 27 pytań. Badania zostały przeprowadzone od marca do maja 2018 r. Obserwacja grup zamkniętych rozpoczęła się w 2016 r. W badaniach brało udział 348 członków kilku grup: Pomysły Plastyczne, Twórcza Świetlica, Plastyka i Technika, Kreatywne Nauczycielki Przedszkola.

Ankieta składała się z pytań zamkniętych jednokrotnego wyboru (13) i zamkniętych wielokrotnego wyboru (9) oraz pytań otwartych (7). Badania przeprowadzono w trzech grupach zamkniętych. Wzięło w nich udział 348 ich członków. Dzięki wyrażeniu zgody przez administratora grupy i jego zaangażo-

\footnotetext{
${ }^{5}$ Na podstawie przeprowadzonych badań własnych na portalu społecznościowym Facebook.
} 


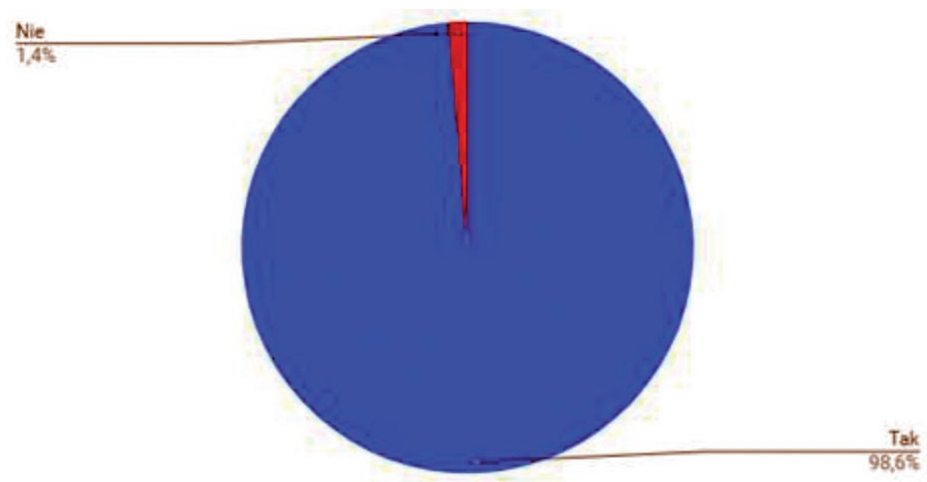

Wykres 1. Pytanie: Czy jest Pani/Pan członkiem grupy zamknietej na FB

waniu możliwe było przeprowadzenie badań ankietowych w hermetycznych obszarach zawodowych.

Respondentkami były wyłącznie kobiety. Największa grupa wiekowa to kobiety w wieku 31-40, następna - w wieku 21-30 lat, kolejna - 41-50 lat. Najmniejszą grupę stanowiły osoby powyżej 60 lat oraz w wieku 51-60 lat.

Przeważały osoby $\mathrm{z}$ wyższym wykształceniem magisterskim $(71,8 \%)$, pozostałe miały licencjat $(16,6 \%)$, wykształcenie policealne (4,4\%) i średnie ogólne $(3,3 \%)$. W grupach były osoby z wykształceniem artystycznym $(9,9 \%)$, technicznym (4,4\%), medycznym (2,2\%) oraz humanistycznym (pozostała grupa).

Respondentki mieszkały w dużych miastach (powyżej 500 tys. mieszkańców - 26\%), małych miasteczkach (20-100 tys. mieszkańców i poniżej 20 tys. mieszkańców - 22,7\%), średnich miastach (poniżej 500 tys. do 200 tys. 9,9\%) oraz na wsi (3,9\%).

Pytania w ankiecie dotyczyły dwóch obszarów. Pierwszy obejmował: edukację plastyczną, jej wykorzystanie w działaniach artystycznych, kształcenie praktyczne, przedstawianie osiągnięć plastycznych i inspiracji. Druga część pytań dotyczyła komunikacji w grupie zamkniętej oraz stosowania netykiety, zasad obowiązujących w komunikacji interpersonalnej, interakcji w świecie wirtualnym.

Pytanie pierwsze dotyczyło członkostwa w grupie oraz charakterystyki jej członków (por. wykres 1).

Najmniej osób w grupie to opiekunki dzieci (nianie zajmujące się dziećmi codziennie $-2,2 \%)$. W grupie byli też rodzice (21\%) i osoby z zamiłowaniem do twórczych działań (45,3\%) oraz nauczyciele (66,9\%). Pojawiły się również studentki i wolontariuszki zajmujące się działaniami plastycznymi, nianie sprawujące opiekę dorywczą i inne osoby mające konto na portalu społecznościowym. 


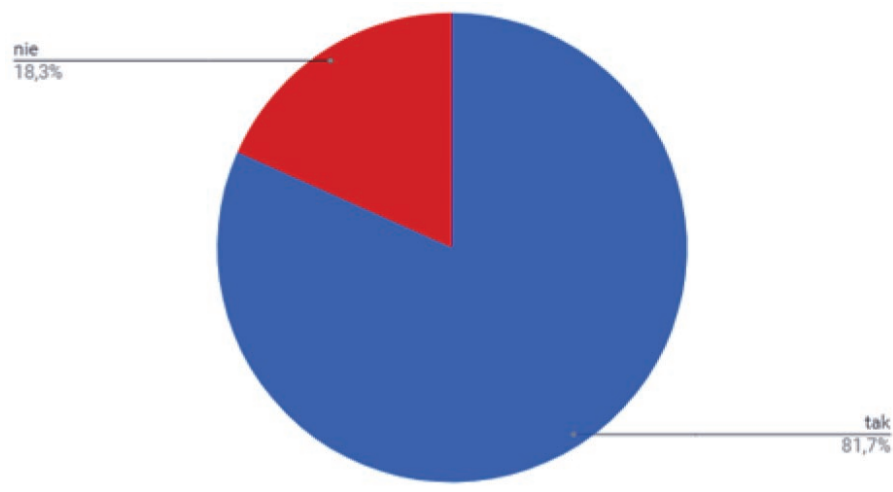

Wykres 2. Pytanie: Czy jest Pani/Pan nauczycielem?

Większość osób w grupach zamkniętych stanowili nauczyciele (por. wykres 2). Najliczniej reprezentowani byli nauczyciele przedszkolni (37,2\%), wczesnoszkolni (25\%), nauczyciele-wychowawcy świetlicy (21,6\%), nauczyciele klas 4-7 (12,8\%), klas „zerowych” (9,5\%), nauczyciele plastyki, techniki, religii i pedagodzy specjalni $(12,8 \%)$ oraz nauczyciele gimnazjum $(5,4 \%)$.

Na pytanie dotyczące częstotliwości odwiedzanej grupy zamkniętej odpowiedzi były różne: bardzo często - codziennie (43,4\%), dość często - kilka razy w tygodniu (36,7\%), często — raz w tygodniu (10\%), czasami - kilka razy w miesiącu $(7,2 \%)$, sporadycznie — raz na kilka miesięcy $(1,1 \%)$. Większość osób $(66,9 \%)$ odwiedza jednak grupę tylko po to, by zamieszczać prace $\mathrm{w}$ formie zdjęć lub krótkich filmików (por. wykres 3).

Większość osób publikuje w grupie własne działania twórcze (38\%). Duża część to prace uczniów (prawie 23\%) i własnych dzieci (około 21\%). Są również

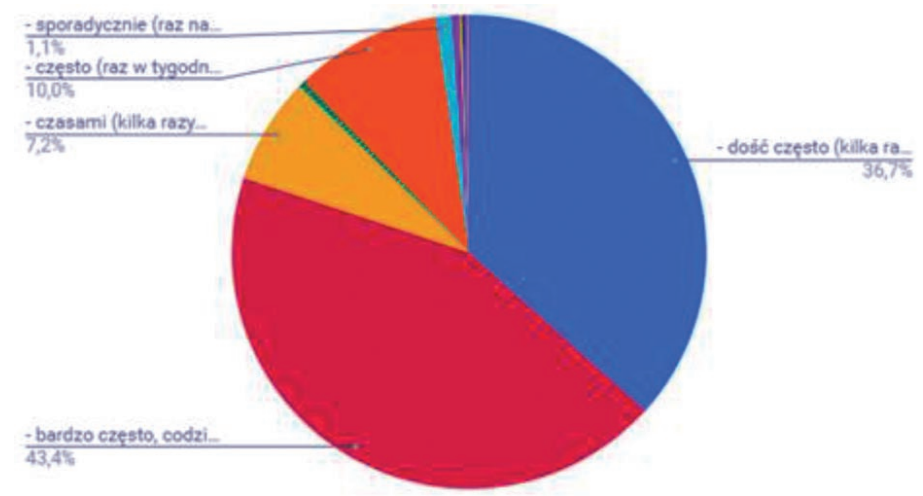

Wykres 3. Pytanie: Jak często odwiedza Pani/Pan grupę artystyczną na portalu? 


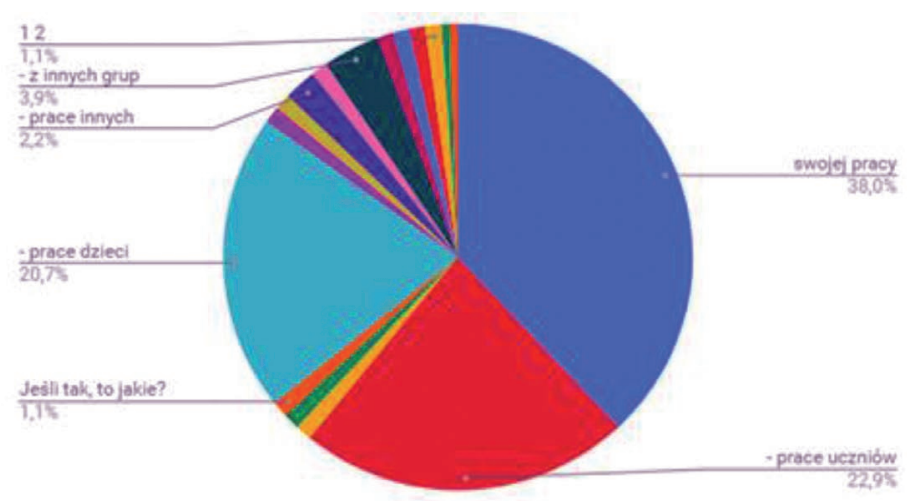

Wykres 4. Pytanie: Czy zamieszcza Pani/Pan na grupie zdjecia?

prace innych osób dorosłych oraz prace $\mathrm{z}$ innych grup także zajmujących się działaniami plastycznymi (por. wykres 4).

Najwięcej inspiracji z grupy jest wykorzystywanych do działań z uczniami podczas zajęć w szkole lub w przedszkolu (77,9\%). Do własnej pracy plastycznej i twórczej inspiracje znajduje tutaj 35,9\% osób, a do działań plastycznych w domu z własnym dzieckiem 33,1\%. Są również osoby, które nie czerpią z grupy inspiracji (por. wykres 5).

Prace własne lub innych większość osób zamieszcza sporadycznie albo raz na kilka tygodni. Niewielka grupa prezentuje prace plastyczne często, ale są też w grupie osoby, które nie zamieszczają ani nie udostępniają swoich prac (por. wykres 6).

Większość natychmiast wyraża opinię co do działania plastycznego i jego efektu (por. wykres 7). Częstotliwość wyrażania opinii zależy od charakteru pracy plastycznej i jakości jej wykonania pracy.

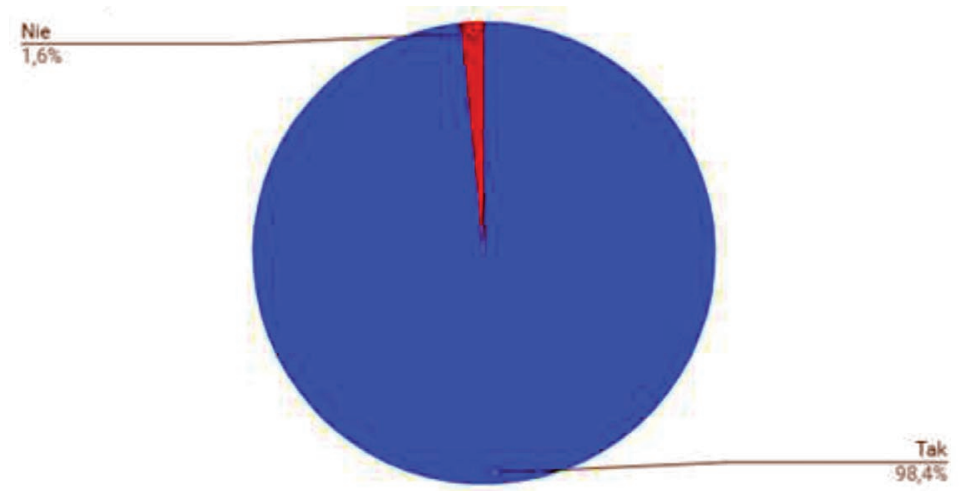

Wykres 5. Pytanie: Czy prace prezentowane w grupie inspirują Panią/Pana do własnych działań? 


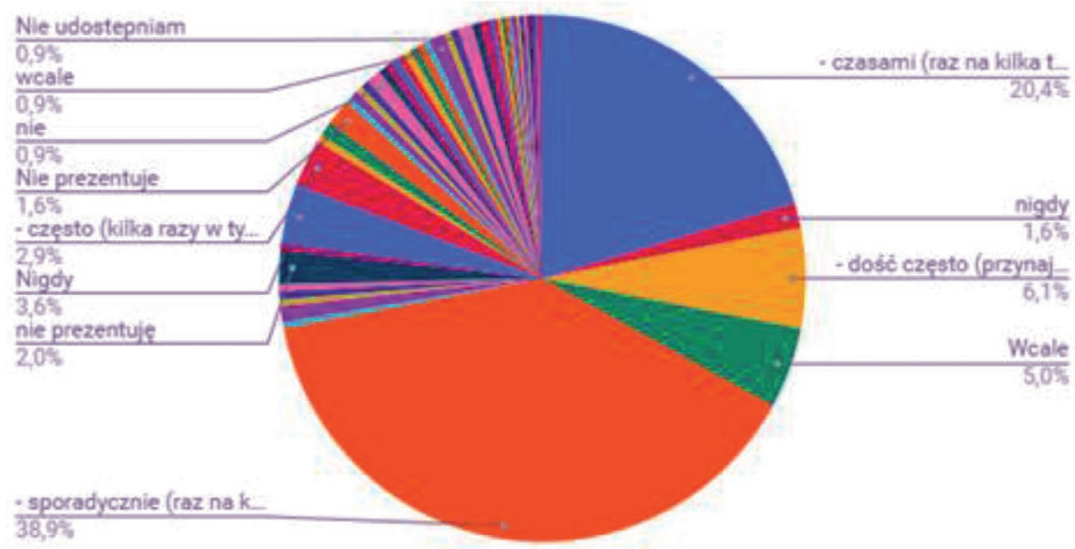

Wykres 6. Pytanie: Jak często prezentuje Pani/Pan swoje prace lub prace innych na grupie?

Wyrażanie opinii - pisanie komentarza pod postem - jest związane z zainteresowaniem pracą (57,5\% osób w grupie), Osoby w grupie chcą wiedzieć, w jaki sposób została ona wykonana (37\%), a także wykorzystać w przyszłości „cudzą" pracę plastyczną do pracy z dziećmi (32,6\%). Pozostałe osoby nie zamieszczają komentarzy pod postem (por. wykres 8).

Ważne pytanie, na które odpowiadały badane osoby, dotyczyło doskonalenia własnego warsztatu pracy plastycznej od strony technicznej. Najwięcej osób doskonali swoje techniki plastyczne, oglądając filmiki na kanale YouTube (59\%). Członkowie grupy podglądają prace zamieszczane w innych grupach $(47,2 \%)$. Są osoby, które dokształcają się wyłącznie podczas szkoleń i warsztatów organizowanych przez instytucje oświatowe. Niektórzy uważają, że należy czerpać inspiracje $z$ różnych grup (16\%), a nieliczni inspirują się wyłącznie pracami w jednej grupie.

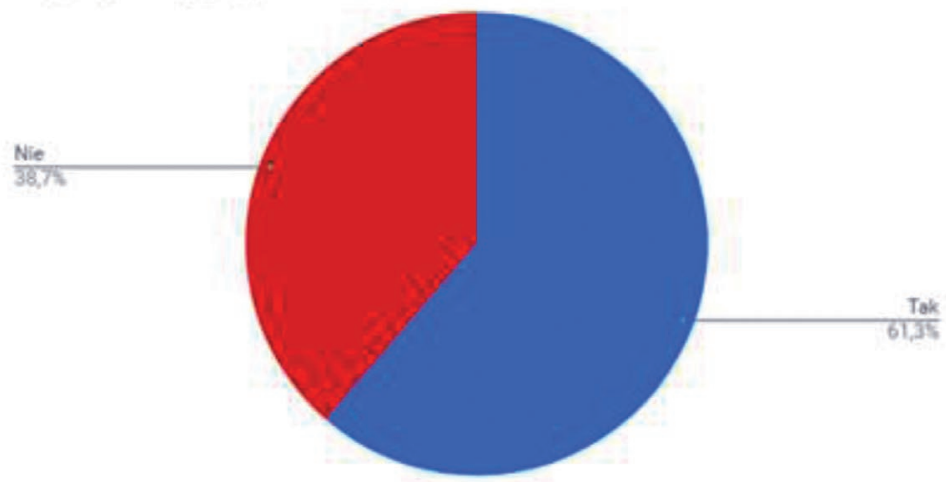

Wykres 7. Pytanie: Czy komentuje Pani/Pan wpisy innych osób w wybranej grupie artystycznej? 


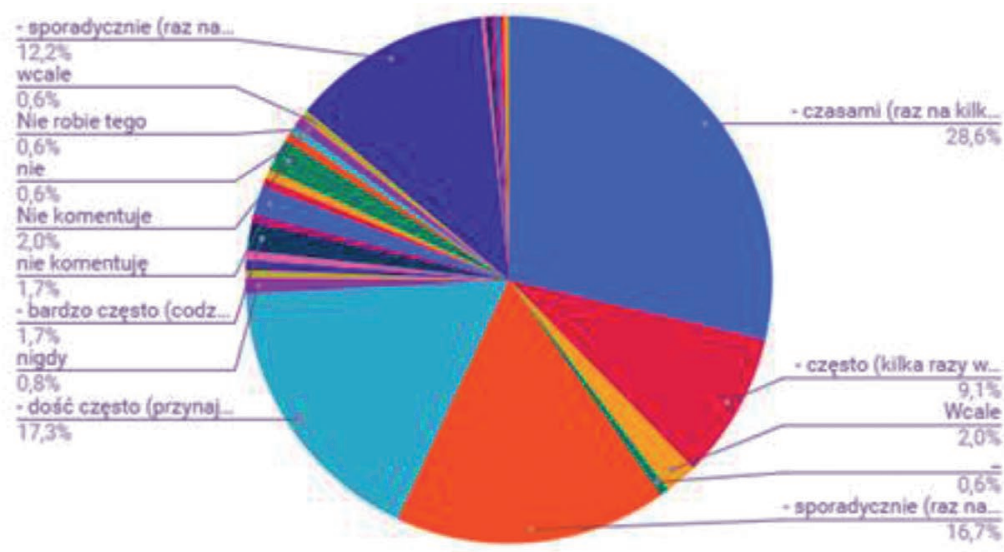

Wykres 8. Pytanie: Jeśli tak, to jak często komentuje Pani/Pan wpisy innych osób?

Ostatnie pytanie z zakresu edukacji plastycznej dotyczyło przynależności do innych grup oraz poznania nazw innych grup zajmujących się tematyką działań plastyczno-technicznych na Facebooku. Badane osoby polecały następujące grupy: Pomysły na Prace Plastyczne, Plastyka i Technika, Kreatywne Nauczycielki Przedszkola, Twórcza Świetlica, Kreatywnie z Dziećmi. Polecały także inne grupy o zbliżonej tematyce: Portal Nauczycieli Przedszkola, Pomoce Dydaktyczne, Sensoplastyka, Daję Rzeczom Drugie Życie, Quilling, Rękodzieło Moje Hobby, Nauczyciele Edukacji Wczesnoszkolnej, Nauczyciel OK, Kidea - Inspiracje, Nauczycielki Przedszkola, DIY Do It Yourself, HandeMade, Kreatywne Prace z Dziećmi, Pomoce Przedszkola.

Pytanie dotyczące wskazania innych grup zajmujących się działaniami plastycznymi zamyka w ankiecie temat edukacji plastycznej.

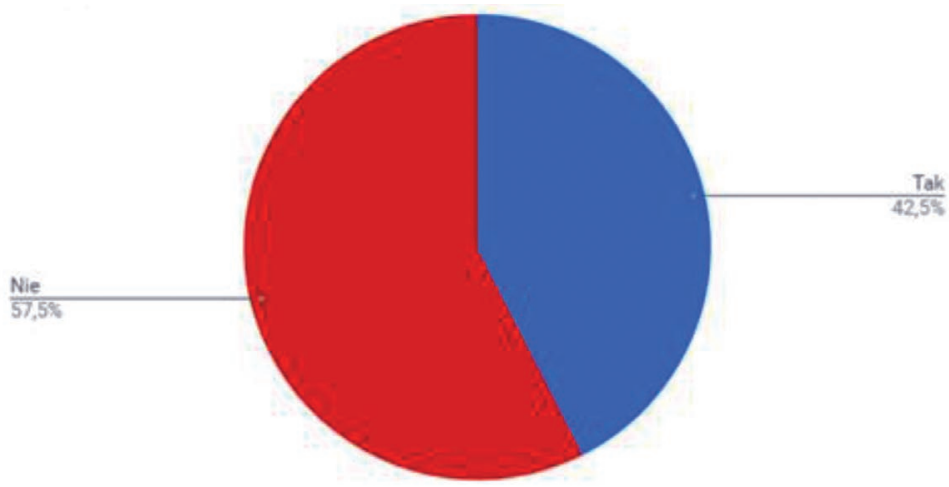

Wykres 9. Pytanie: Czy komunikuje się Pani/Pan z innymi członkami wybranej grupy? 


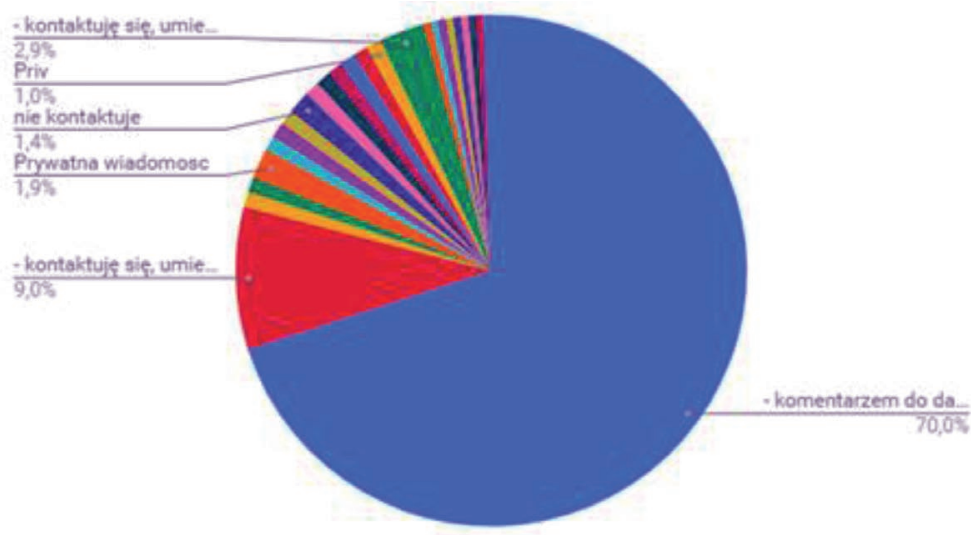

Wykres 10. Pytanie: Jeśli tak, to w jaki sposób?

Następny temat badań w ankiecie dotyczył komunikacji interpersonalnej w grupie zamkniętej. Poniżej przedstawiono odpowiedzi badanych osób na zadane pytania.

Członkowie grupy komunikują się w większości z innymi osobami w wybranej grupie (wykres 9).

Sposób, w jaki to robią, zależy od indywidualnych umiejętności posługiwania się nowymi technologiami (aplikacje). Większość osób (70\%) komunikuje się w grupie, pisząc komentarz do danego postu. Niektóre osoby umieszczają go na głównej stronie grupy (9\%). Inne osoby wysyłają prywatną wiadomość, używając aplikacji Messenger lub maila (4,8\%). Pozostałe osoby nie kontaktują się wcale (por. wykres 10).

Kolejne pytanie dotyczyło komunikacji członków grupy poza grupą, tzn. $\mathrm{w}$ świecie realnym. Większa część badanych osób nie przenosi komunikacji ze

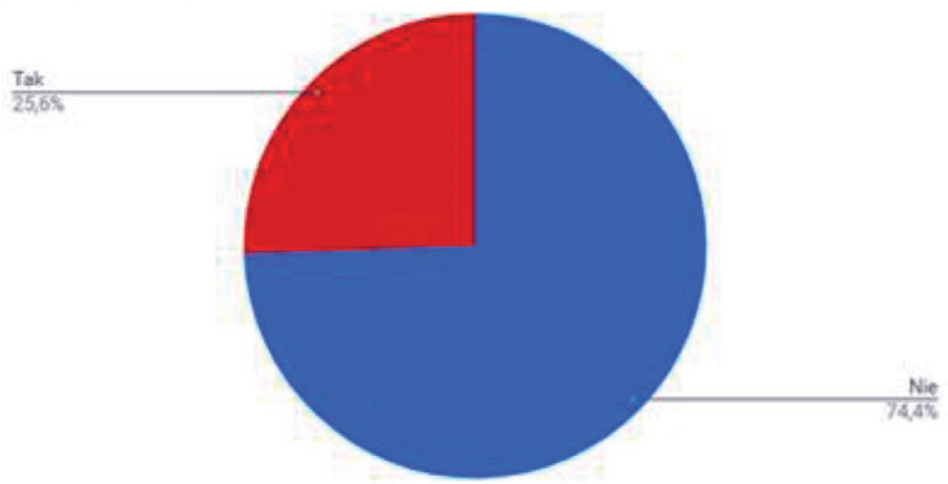

Wykres 11. Pytanie: Czy nawiązuje Pani/Pan komunikację (rozmowę) z kimś z grupy poza portalem, prywatnie? 


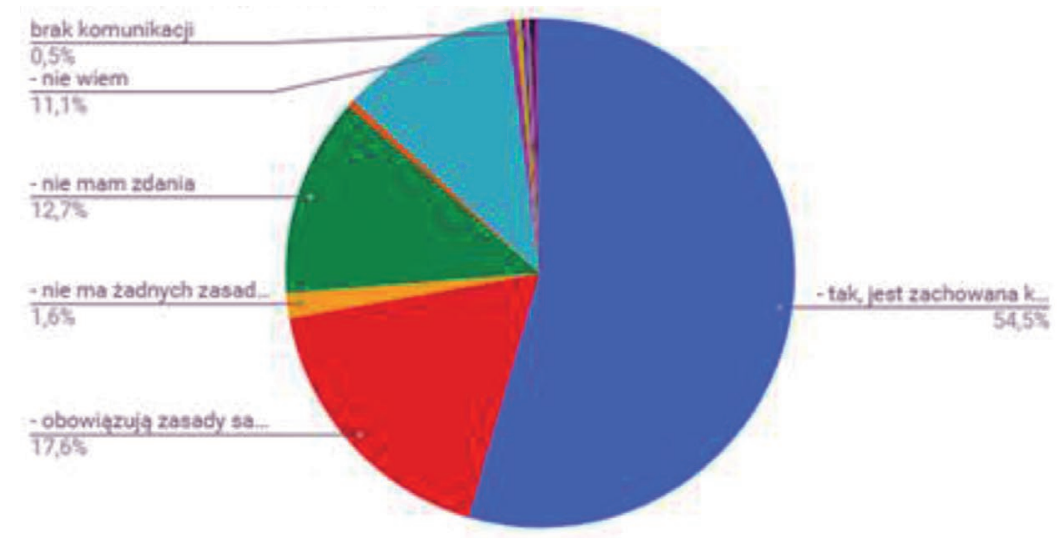

Wykres 12. Pytanie: Czy komunikacja interpersonalna między członkami grupy przebiega według ustalonych zasad?

świata wirtualnego do świata realnego. Jedynie nieduża część inicjuje i kontynuuje rozmowę przy użyciu nowych technologii (por. wykres 11).

Osoby, które przenoszą komunikację do świata rzeczywistego, komunikują się za pośrednictwem aplikacji Messenger (71,1 \%), wysyłają maila na prywatny adres $(8,9 \%)$, potem komunikują się telefonicznie $(20 \%)$. Reszta nie przenosi relacji ze świata wirtualnego do rzeczywistości.

Główne pytanie do respondentów dotyczyło jakości komunikacji i jej przebiegu, kultury słowa i form grzecznościowych. Większa część badanych uważa, że kultura słowa w grupach zamkniętych jest zachowana. Część jest przekonana, że obowiązują zasady savoir-vivre'u (17,6\%). Część (12,7\%) nie ma zdania na temat tych zasad i nie zna ich. Jedynie niewielka liczba osób $(1,6 \%)$ uważa, że w grupie nie panują zasady kultury słowa (por. wykres 12).

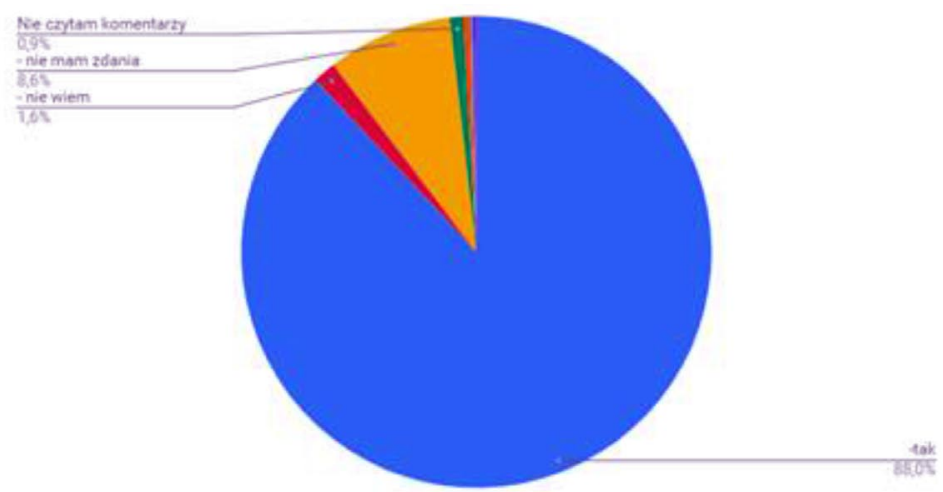

Wykres 13. Pytanie: Czy ważny jest dla Pani/Pan poziom jakosci kultury komunikacji interpersonalnej w grupie? 


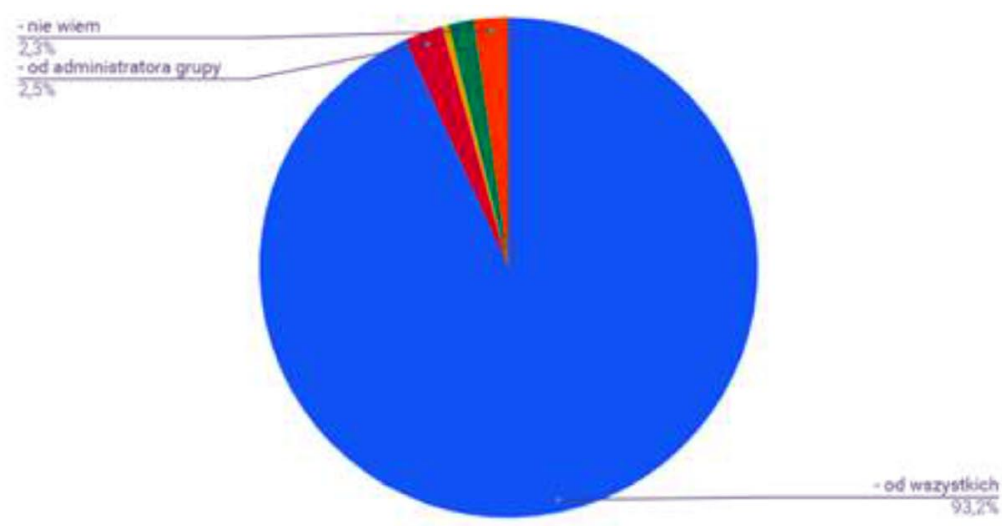

Wykres 14. Pytanie: Od kogo zależy poziom jakości kultury komunikacji interpersonalnej w grupie?

Odpowiadając na pytanie o ważność poziomu jakości komunikacji interpersonalnej $\mathrm{w}$ grupie, $88 \%$ ankietowanych ją potwierdziło, $8,6 \%$ nie ma zdania, a jedynie $1,6 \%$ nie wie i $0,9 \%$ nie czyta komentarza (por. wykres 13 ).

W odpowiedzi na kolejne pytanie, dotyczące jakości kultury komunikacji w grupie, ankietowani stwierdzili , że poziom kultury zależy w dużej mierze od członków grupy $(93,2 \%)$.

Niewielka liczba osób uważa, że poziom kultury w grupie zamkniętej zależy od administratora lub administratorów (adminów) grupy; 2\% osób uważa, że poziom kultury zależy od każdego członka grupy (por. wykres 14).

Znajomość zasad etykiety $\mathrm{w}$ świecie wirtualnym (netykiety) demonstrują osoby, które potrafią się nią posługiwać, znają zasady savoir-vivre'u i stosują je w interakcjach. Część osób w grupie (14,3\%) nie zna zasad netykiety, ale chciałaby je poznać, by lepiej się komunikować (9,5\%) (por. wykres 15$)$.

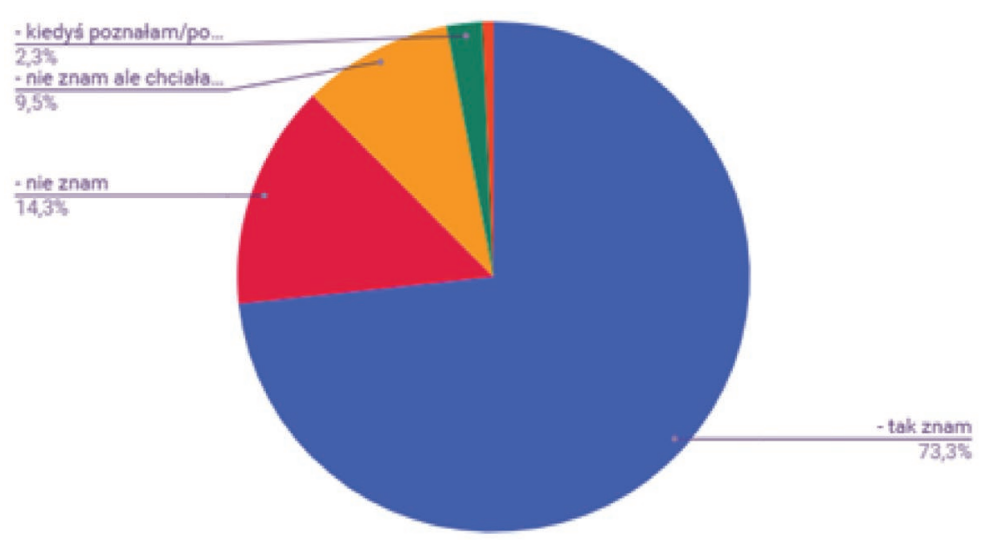

Wykres 15. Pytanie: Czy zna Pani/Pan zasady netykiety? 


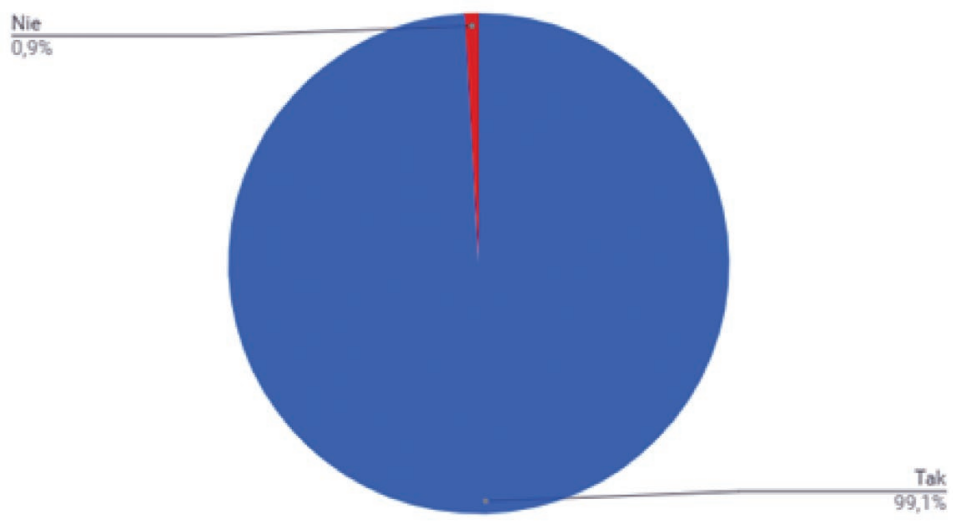

Wykres 16. Pytanie: Czy łatwo było Pani/Panu zostać członkiem tej grupy?

Dla dużej grupy osób (89\%) bardzo ważny jest poziom kultury słowa. Nie ma zdania na ten temat 7,7\%, a nieliczne osoby wcale nie myślą o poziomie kultury w komunikacji w grupie.

Na pytanie, czy łatwo było zostać członkiem grupy, blisko 100\% osób udzieliło odpowiedzi twierdzącej $(99,1 \%)$ (por. wykres 16$)$.

O potrzebie istnienia takich grup zamkniętych wypowiada się pozytywnie 92,5\% badanych, 3,6\% uważa, że nie są one potrzebne, 0,5\% zaś myśli, że są przydatne dla innych.

Respondentki uważają, że istnieje potrzeba działania takich grup, ponieważ są one: „doskonałym źródłem inspiracji”, „kopalnią pomysłów”, „źródłem informacji i wymiany doświadczeń”, ponadto: „dają możliwość stworzenia wspólnych projektów”, „pomagają w pracy z dziećmi”, „tworzą wymianę myśli mię-

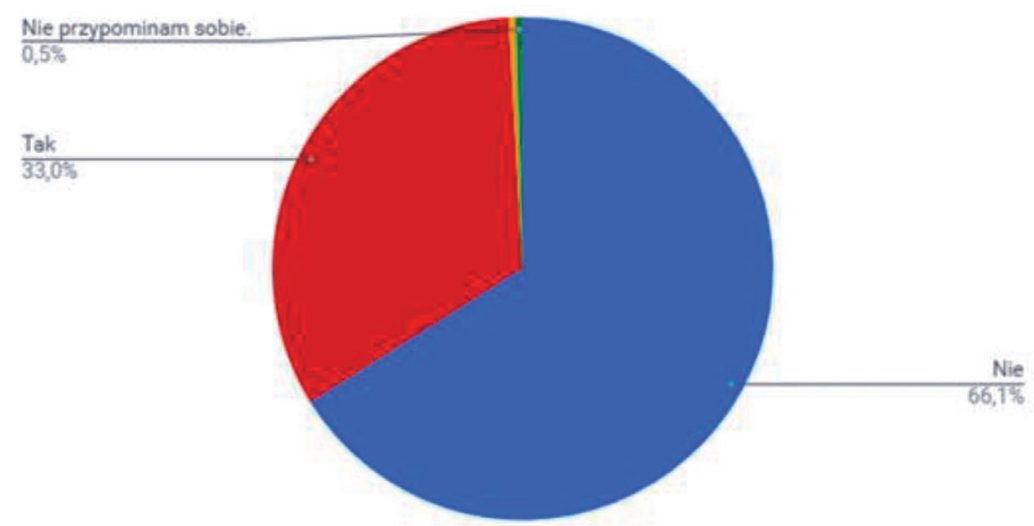

Wykres 17. Pytanie: Czy zdarzyło się Pani/Panu przenieść znajomość ze świata wirtualnego do świata realnego? 
dzy nauczycielami”, „wzbogacają warsztat pracy”, dają możliwość „poznania nowych osób”, „tworzenia pięknych rzeczy”, „,sprawiają satysfakcję nauczycielom i uczniom” oraz „wyjaśniają stronę techniczną tworzenia pracy plastycznej".

Ostatnie pytanie dotyczyło rzeczywistości i świata wirtualnego. Pytanie brzmiało: „Czy zdarzyło się Pani/Panu przenieść znajomość w grupie ze świata wirtualnego do świata realnego?". Ponad połowa osób $(66,1 \%)$ nie przeniosła znajomości w świat realny, 33\% badanych znajomość przeniosło, a 0,5\% respondentów nie przypomina sobie (por. wykres 17).

Jak wynika z przeprowadzonych badań, grupy zamknięte pełnią wiele funkcji. Są inspiracją dla nauczycieli, studentów i rodziców. Kreatywnie wpływają na twórcze działania plastyczne. Tworzą płaszczyznę wymiany poglądów. Są miejscem, w którym członkowie grupy dokształcają się, wymieniają informacje, nawiązują nowe relacje, inicjują wspólne projekty. Budują nowy, zamknięty świat, w którym ważną rolę odgrywa etykieta przeniesiona ze świata rzeczywistego. Każda grupa ma swoje formalne zasady, których członkowie przestrzegają. Osoby działające w tych grupach chcą poznać zasady savoir-vivre'u, aby zachować wysoki poziom kultury słowa, niezbędny, by dostosować się do regulaminu grupy. Członkowie społeczności wchodzą w interakcje, przenoszą komunikację interpersonalną ze świata wirtualnego do świata rzeczywistego za pomocą aplikacji Messenger, która połączona jest z portalem społecznościowym i dostępna jest w każdym miejscu świata rzeczywistego. Świat wirtualny przenika do świata rzeczywistego, a my wraz z nim. Teraz już jesteśmy zawsze online. Nauczanie on-line, powszechne dziś w szkołach podstawowych i średnich, ułatwia nauczycielowi prowadzenie zajęć artystycznych, ponieważ umożliwia natychmiastowe udostępniania materiałów dydaktycznych.

Nauczyciel plastyki powinien dążyć do twórczego, aktywnego działania uczniów podczas zajęć dydaktycznych. Ma bowiem przygotowywać ich do świadomego udziału w kulturze oraz zastosowania nabytej wiedzy w innych dziedzinach życia.

Podstawa programowa uwzględnia kluczowe kompetencje zawarte w zaleceniach europejskich, które rozwijają świadomość kulturową przez:

- poczucie związku z tradycją narodową;

- uczestniczenie w życiu kulturalnym;

- docenianie estetyki w życiu codziennym;

— posługiwanie się językiem sztuki;

— znajomość najważniejszych dzieł, które należą do dziedzictwa kultury.

Podstawa programowa w zakresie plastyki dąży do kształtowania postawy twórczej, nastawionej na nabywanie wiedzy i umiejętności, które prowadzą do wychowania człowieka innowacyjnego, uczestniczącego w kulturze i w jej upowszechnianiu. Realizacja podstawy programowej wymaga odpowiednich warun- 
ków do przeprowadzenia zajęć dydaktycznych. Szkoła powinna zapewnić niezbędne środki dydaktyczne $\mathrm{z}$ możliwością pozostawiania ich w szkole.

Wychowanie estetyczne jest w plastyce bardzo ważne i istotne. Stefan Szuman traktował nauczyciela jako osobę wychowaną estetycznie, która ma pełnić rolę doradczą i ukierunkowującą wobec sztuki. Wychowawca ma pomagać wychowankowi w odbiorze sztuki, która ma być przeżywana i poznawana w sposób aktywny i samodzielny. Pedagog powinien ułatwiać zrozumienie sztuki, pokazywać to, co na pierwszy rzut oka jest niedostrzegalne, i uczyć jej odbioru. Metodą, jaką stosuje wychowawca estetyczny, jest rozmowa, która prowadzi do lepszego poznawania i przeżywania twórczości.

Odwołując się do poglądów Szumana, należy stwierdzić, że wychowawca estetyczny powinien:

— przeżywać i rozumieć sztukę;

— posługiwać się jej językiem — językiem współczesnym;

- odznaczać się kompetencją komunikacyjną;

- mieć przygotowanie z zakresu konkretnej dziedziny sztuki.

Wychowawcą estetycznym może zostać artysta, prywatny miłośnik i znawca sztuki lub nauczyciel i wychowawca (Szuman, 1975, s. 112).

Te cechy osobowości budują konkretną postawę pedagogiczną nauczyciela, którą przejawia się $\mathrm{w}$ relacjach nauczyciela $\mathrm{z}$ samym sobą, $\mathrm{z}$ drugim człowiekiem - uczniem, rodzicem, nauczycielami i z otaczającą go rzeczywistością. Owe interakcje pozostają ze sobą w ścisłym związku. Każde spotkanie z uczniem wymaga od nauczyciela wielu umiejętności. Poczucie odpowiedzialności powinno towarzyszyć mu zawsze (s. 119).

Współczesna edukacja jest coraz trudniejsza. Zmieniające się środowisko, rozwój myśli technologicznej to czynniki, które powodują potrzebę zmian w systemie kształcenia i doskonalenia nauczycieli. Edukacja artystyczna ma za zadanie przygotowanie do wyzwalania potencjału twórczego ucznia, przezwyciężenie narastających napięć między tradycją a nowoczesnością, tym, co uniwersalne, i tym, co jednostkowe, tym, co lokalne, i tym, co globalne, a także między rozwojem wiedzy a zdolnością asymilowania jej przez człowieka. Dlatego współczesny nauczyciel musi być człowiekiem wrażliwym, mądrym, twórczym i krytycznym. Powinien wskazywać uczniowi różne możliwości indywidualnej drogi rozwoju, znalezienia tożsamości oraz samorealizacji. Wszelkie działania twórcze podejmowane przez nauczyciela znacznie podwyższają skuteczność jego pracy (Krzywoń, 2005, s. 88).

Współczesny pedagog to skuteczny nauczyciel, który nie stresuje ucznia, wymaga, ale nie narzuca, i utrzymuje dyscyplinę, nie używając przymusu. To osoba sprawiedliwa, która w każdym zobaczy coś dobrego, dostrzeże i rozwinie potencjał uczniów zdolnych, a równocześnie pomoże słabszym. Nauczyciel, który jest znawcą duszy młodych, będzie ich sprzymierzeńcem, mistrzem i autorytetem. 
W poszukiwaniu inspiracji nauczyciel korzysta $\mathrm{z}$ zasobów internetowych. Tworzenie nowych zasobów wiedzy na bazie umiejętności i zdolności innych to zbiorowa inteligencja. Ta zbiorowa inteligencja jest zdolnością wirtualnych społeczności do podnoszenia poziomu wiedzy i kompetencji eksperckich ich członków przez współpracę i debaty prowadzone na dużą skalę (Jenkins, 2007, s. 256). Połączona wiedza (i inteligencja) wielu osób, wspólne tworzenie w ten sposób nowych znaczeń oraz rozwiązywanie problemów kreują wielką siłę i stanowić mogą alternatywę dla dominującej do tej pory unikatowej wiedzy eksperckiej (Zalewska-Pawlak, Soszyński (red.), 2015, s. 244).

Ranga edukacji estetycznej wzrasta w obecnym multikulturowym i cyfrowym społeczeństwie tym bardziej, im bardziej skłaniamy się ku kulturze obrazkowej. Grupy zamknięte zajmujące się edukacją plastyczną są tego przykładem.

Współczesna rzeczywistość szkolna oraz świat nowych mediów powoli staje się nieograniczonym źródłem wiedzy o metodach kształcenia i wychowania w świetle współczesnej kultury konwergencji (s. 248). Dziecko na każdym etapie kształcenia styka się ze światem nowych mediów, a to daje możliwość poznania i wykorzystania technik medialnych w jego działaniach twórczych.

Systemy medialne współegzystują ze sobą, tworząc kulturę konwergencji, a tym samym stają się czynnikiem wzbogacającym proces kształcenia dzieci i młodzieży, nie zmieniając zasadniczo idei wychowania przez sztukę i twórczość artystyczną. Wykorzystanie edukacyjnego potencjału mediów stanowi zatem właściwy kierunek poszukiwań i wskazuje perspektywę zmian w praktyce edukacyinej (Zalewska Pawlak, 2017, s. 129).

Edukacja plastyczna jest przedmiotem interdyscyplinarnym. Odchodzi od tradycyjnych narzędzi, takich jak papier, ołówek czy farby, zastępując je fotografia, programem graficznym czy aplikacją. Współczesny nauczyciel doskonali i rozwija swój warsztat pracy, poszukując inspiracji w świecie wirtualnym, zachęcając ucznia do aktywności twórczej, w której wykorzysta komputer i internet jako narzędzia własnego kreatywnego działania plastycznego w szkole i poza nią.

\section{Wybrane grupy zamknięte zajmujące się edukacją plastyczną na portalu społecznościowym}

\section{Pomysły na Prace Plastyczne}

Grupa zamknięta zajmująca się edukacją plastyczną. Typ: grupa wspólnej nauki. Członkowie grupy zobowiązani są do przestrzegania regulaminu, który jest opublikowany na stronie grupy. 


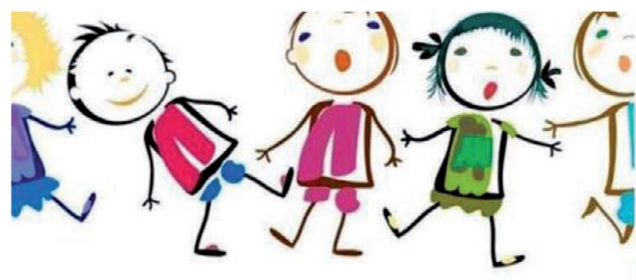

Nauczyciele Przedszkola 힐욜 $\vee$

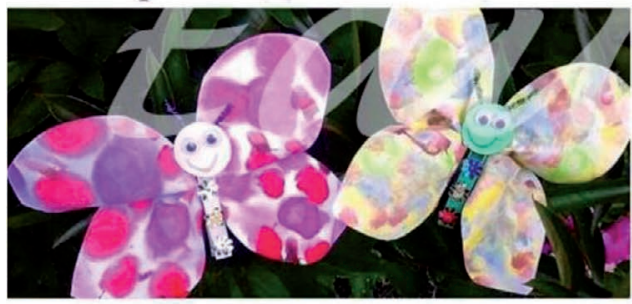

Kreatywnie z dziećmi v
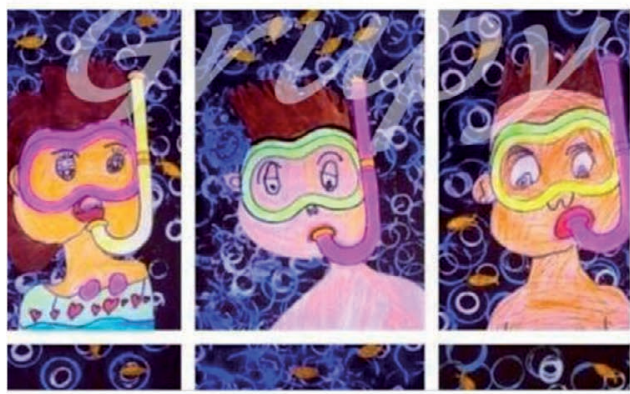

Pomysły na prace plastyczne $\checkmark$

G Grupa zamknięta 103 tys. członków
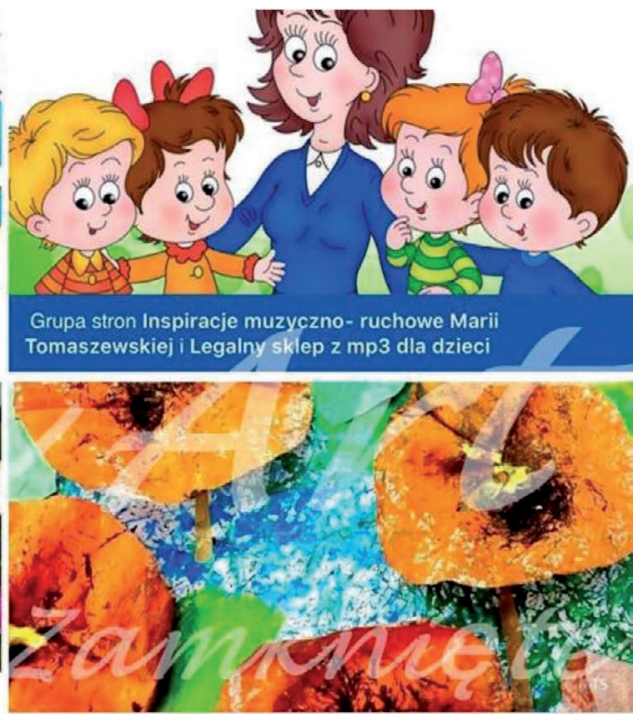

a Twórcza Świetlica

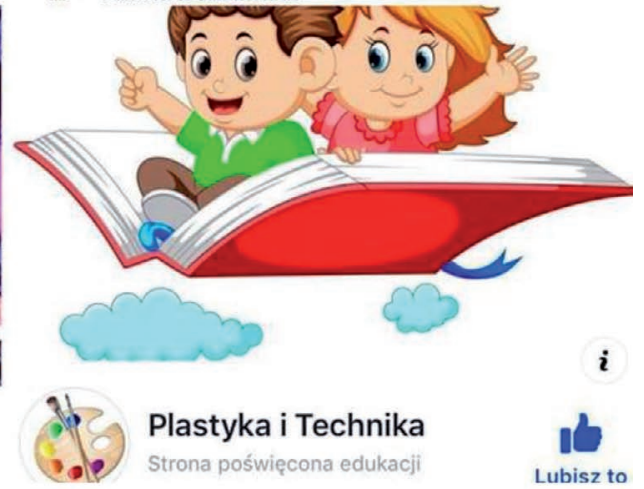

mi w wieku przedszkolnym i szkolnym. Członkowie wymieniają się w̧ฐ̧zukanymi przykładami prac plastycznych. Oczywiście mile widziane są własne pomysły! $2:$ :) Robimy fqtki i publikujemy je w naszej grupie, opisując krótko pracę (słowa klucze poprzedzone \#) prac powinien nawiązywać do bieżącej pory roku tudzież uroczystości okolicznościowych. Proszę wszystkich o dokładne przeczytanie regulaminu grupy i zastosowanie się do niego. Każdy post nie na temat, jak również bez \#tagów, nie zostanie opublikowany. To nie jest grupa sprzedażowa! Wszelkie posty $z$ ofertą sprzedaży nie zostaną opublikowane. Jeśli ktoś ma ochłotę podziękować za przyęcie do grupy, to bardzo proszę, aby to były merytoryczne posty ${ }^{-}$¿:) z pomysłem na prace w bieżącym temacie (bieżący temat jest określany przez porę roku, uroczystości itp. $)^{6}$.

${ }^{6}$ Badania własne na portalu społecznościowym Facebook, 27 V 2018. 
Grupa liczy 103349 członków. Powstała 27 września 2013 r. Obsługiwana jest przez dwóch administratorów i moderatora.

Twórcza Świetlica

Grupa zamknięta, zajmująca się edukacją plastyczną i wymianą doświadczeń przez nauczycieli i osoby pracujące $\mathrm{w}$ świetlicach szkolnych i środowiskowych oraz innych placówkach opiekuńczo-wychowawczych. „Celem grupy jest dzielenie się pomysłami na ciekawe zajęcia, imprezy, działania, dekoracje itp. oraz wszelka wymiana doświadczeń zawodowych"7.

Grupa liczy 6539 członków, prowadzi ją jeden administrator. Nie ma regulaminu. Powstała w marcu 2016 r.

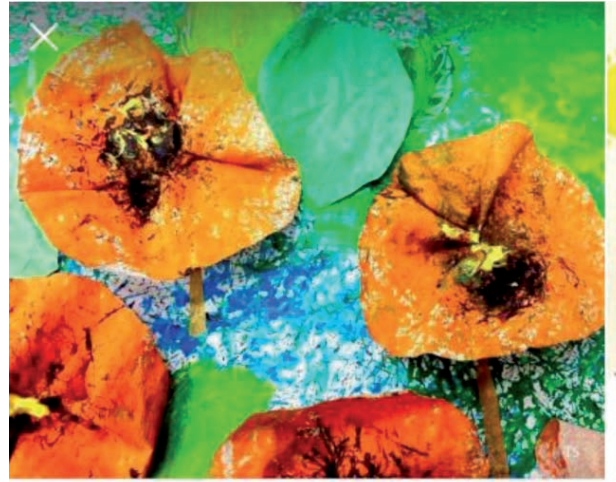

a Twórcza Świetlica

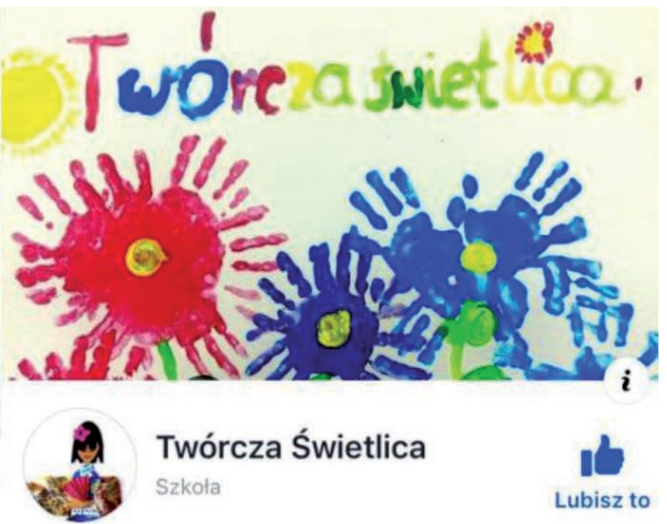

Plastyka i Technika

Strona powstała 6 stycznia 2013 r. Ma grupę otwartą o tej samej nazwie. Liczba członków wynosi 1327, grupę obsługuje jeden administrator. Strona jest również administratorem grupy. Zawiera propozycje prowadzenia zajęć plastycznych z dziećmi w szkole, przedszkolu i w domu. Nie ma regulaminu.

Strona Plastyka i Technika ma 139 tys. obserwujących stronę; grupa liczy 1326 członków.

\footnotetext{
${ }^{7}$ Badania własne na portalu społecznościowym Facebook, 27 V 2018.
} 


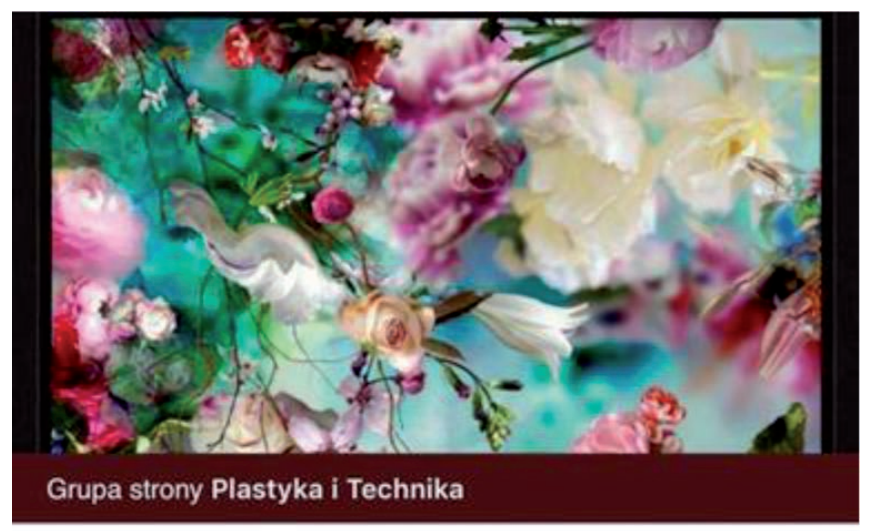

\section{Plastyka i Technika $v$}

\section{(1) Grupa otwarta $\cdot 1,3$ tys. czlonków}

Kreatywnie z Dziećmi

Grupa zamknięta dla nauczycieli. „Grupa dla Wszystkich Mam, które lubią razem z Dzieciaczkami kreatywnie potworzyć, i dla Nauczycieli Przedszkoli, którzy z podopiecznymi nieustannie kreatywnie działają. Chcecie pochwalić się stworzonymi pracami? A może szukacie inspiracji? To miejsce jest właśnie po to".

Grupa liczy 23473 członków, ma jednego administratora. Nie ma swojego regulaminu. Jest to typ grupy „rodzina”.

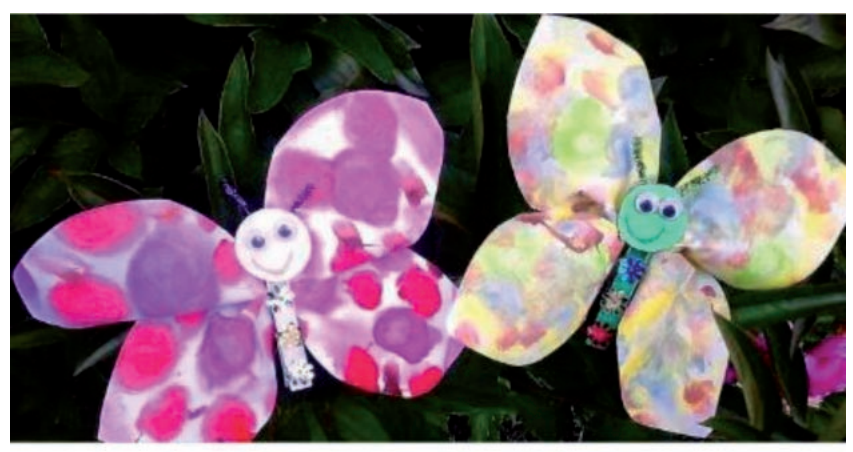

\section{Kreatywnie z dziećmi $\vee$}

G Grupa zamknięta $\cdot 23,4$ tys. członków 
Inne grupy, z których można czerpać inspirację:

Kreatywne Nauczycielki Przedszkola

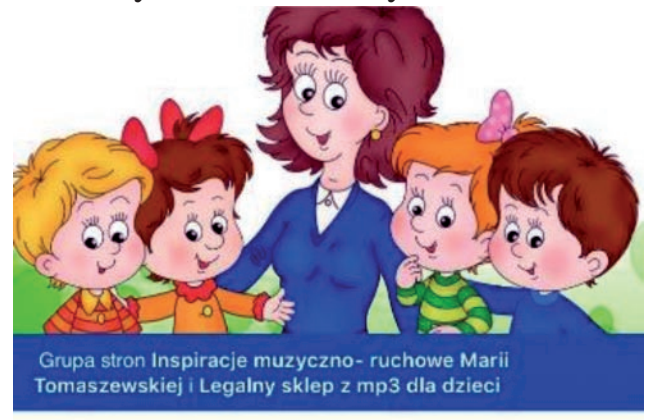

Kreatywne Nauczycielki

Przedszkola $\vee$

Nauczyciele Przedszkola

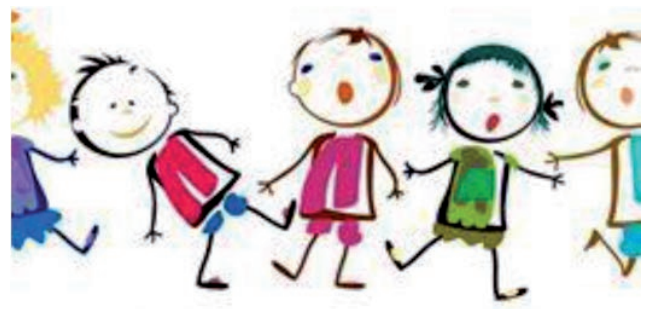

Nauczyciele Przedszkola 닐 $~$

G Grupa zamknięta : 4,9 tys. czlonków

Plastyczne Inspiracje dla Nauczycieli Przedszkola

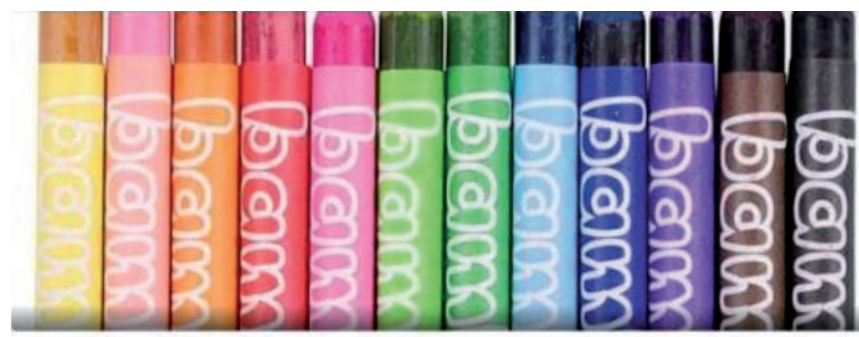

Plastyczne Inspiracje dla Nauczycieli Przedszkola i Szkoly 


\section{Bibliografia}

Jenkins, H. (2007). Kultura konwergencji. Zderzenie starych i nowych mediów. Przeł. M. Bernatowicz. Warszawa: Wyd. Akademickie i Profesjonalne.

Kirkpatrick, D. (2011). Efekt Facebooka. Przeł. M. Lipa. Warszawa: Wolters Kluwers.

Krzywoń, D. (2005). Wyzwalanie potencjatu twórczego przysztych nauczycieli. W: W. Limont, K. Nielek-Zawadzka (red.), Edukacja artystyczna wobec przemian w kulturze. „Dylematy Edukacji Artystycznej”, 1. Kraków-[Toruń]: Impuls-UMK.

Levinson, P. (2010). Nowe nowe media. Przeł. M. Zawadzka. Kraków: WAM.

Szuman, S. (1975). O sztuce $i$ wychowaniu estetycznym. Wyd. 3 uzup. Warszawa: WSiP.

Zalewska-Pawlak M. (2017). Sztuka i wychowanie w XXI wieku. W poszukiwaniu zagubionej teorii sztuki życia $i$ sztuki wychowania. Łódź: Wyd. UŁ.

Zalewska-Pawlak, M., Soszyński P. (red.). (2015). Sztuka i wychowanie w kulturze konwergencji. Wyzwoleni $i$ zagubieni w sieci. Łódź: Wyd. UŁ. 